\title{
ANALYSIS OF COMPOSITE ELECTRIC VEHICLE BODY
}

\author{
Lydia Anggraini ${ }^{1, a}$, Ida Bagus Madra Gana ${ }^{2, b}$ \\ 1,2School of Mechanical Engineering, President University \\ Jababeka Education Park, Jl. Ki Hajar Dewantara, Cikarang, Bekasi, Indonesia \\ alydia.anggra@president.ac.id, bganamadra@gmail.com
}

\begin{abstract}
Abstrak
Makalah ini menyajikan studi tentang bodi mobil berbahan komposit menggunakan metode elemen hingga. Bodi mobil tersebut terbuat dari model permukaan dan penelitian dilakukan untuk mensimulasikan kemungkinan deformasi bodi di bawah beban tertentu. Tujuannya adalah untuk menemukan ketebalan ideal bodi komposit untuk meminimalkan bobot kendaraan. Dalam penelitian ini, analisis kekuatan menggunakan elemen hingga akan dijelaskan dan deformasi bodi diselidiki untuk menemukan kemungkinan untuk meningkatkan penelitian ini.
\end{abstract}

Kata kunci. Kendaraan Listrik, Tubuh Luar, Komposit, Fiberglass, Metode Elemen Hingga

Abstract

This paper presents a study of a composite car body using finite element method. The body is made of surface model and the study is conducted to simulate the possible deformation of the body under certain load. The objective is to find tha ideal thickness of the composite body as to minimize the vehicle weight. In this research, the strength analysis using finite elements will be explained and the deformation of the body is investigated for finding a possibility to improve this research.

Keywords. Electric Vehicle, Outer Body, Composite, Fiberglass, Finite Element Method

\section{Introduction}

Nowadays, vehicle become important thing for people, especially for people who live in big cities. Vehicle can make easier for people to move to a place far from home. There are several types of vehicles commonly found in the city such as car, motorcycle, bus, truck and the other. Most of these vehicles have been driven by the combustion engine, it is quite hard to find vehicles that are driven by humans or pulled by animals. People prefer to use car compared to other vehicles, this is because car is more comfortable and practical.

Cars with internal combustion engine have several disadvantages such as air pollution, the greenhouse effect, using fossil fuels and much more [1]. In order to deal with this problem, many countries and automotive companies in particular are competing to develop cars with electric engine. Indonesia is one of the countries that has contributed to the development of electric cars. It is known that Indonesia has national car with a combustion engine but, in 1998 Indonesia experienced a Monetary Crisis which forced the national car company to close [2]. At this time, it seems too late to rebuild a national car with an internal combustion engine where other countries already have far more advanced technology but, this is the right time and opportunity to start building electric cars because other countries are just starting to build it. There are some of the Indonesian electric cars that has been successfully developed such as Tucuxi Electric Car, Gendhis Electric car, Selo Electric car, Evina Electric car and Hevina Electric car [3].

An electric car is a car that are driven by an electric motor as the main driver by using electrical energy stored in the battery. Electric car has several factors of excellence when compared to internal combustion engine car. The most impact is the electric cars do not produce the emissions, so reduces the greenhouse effect due to no more fossil fuels used [1]. There are several main components of 
electric cars such as batteries, electric engines, chassis, outer body and much more. One component that can be developed is the outer body, how to develop this part to be lighter and stronger. The outer body is an important part of the car that must has strong construction. In general, the outer body use materials such as steel or other metal material. On the other hand, with the advances of the technology it can be determined by the use of other materials.

Some vehicle bodies use non-metallic materials, one of the non-metallic materials is fiberglass. Fiberglass is an alloy material or mixture of several chemicals which reacts and hardens at a certain time. This material has several advantages over metal materials, including: lighter, easier to form and cheaper. The character of fiberglass is the toughness of high-strength materials, and does not experience abrasion and corrosion [4].

\section{Research Methodology}

This research is about analysis of outer body of electric vehicle made of composite material, to determine the thickness of car body which is on process of being made in the President University lab. The outer body is made of Fiberglass (E-Glass) which is Mat type (discontinuous fiber composites). Outer body is the surface that covers the chassis which must have less weight as much as possible and be quite rigid. The use of fiberglass in making the outer body can reduce weight and provide adequate strength with minimal costs. The fabrication can eliminate the use of machines because it can be done as in-house fabrication so it saves manufacturing costs. This technique gives more flexibility in design because it can be made as desired. Manufacturing materials are also easily available in the local market.

Table 1. Electric Vehicle Data

\begin{tabular}{c|c}
\hline Specification & Dimension \\
\hline Overall Length & $2350 \mathrm{~mm}$ \\
Overall Width & $1260 \mathrm{~mm}$ \\
Overall Height & $1625 \mathrm{~mm}$ \\
Wheel Base & $1660 \mathrm{~mm}$ \\
Ground Clearance & $130 \mathrm{~mm}$ \\
\hline
\end{tabular}

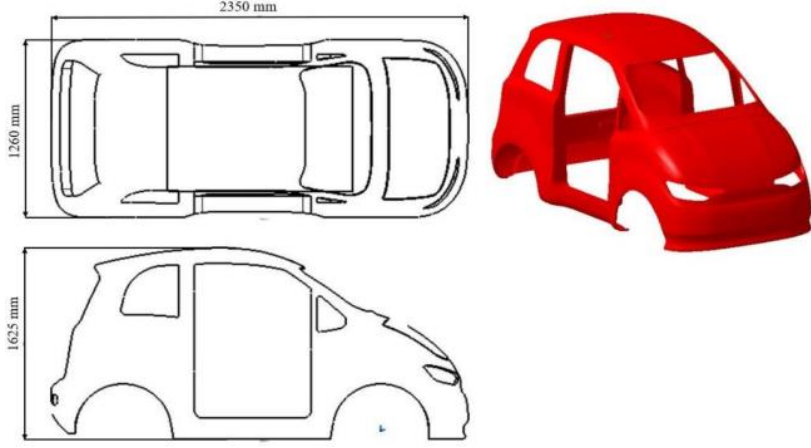

Figure 1. Design of Electric Vehicle Body

The material made by fiberglass (E-glass) with density of $2.58 \times 10^{3} \mathrm{~kg} / \mathrm{m}^{3}$, Tensile Strength of 207 $\mathrm{MPa}=2.07 \times 10^{8} \mathrm{~N} / \mathrm{m}^{2}$, Poisson Ratio of 0.23 , Young Modulus of $2.43 \times 10^{9} \mathrm{~N} / \mathrm{m}^{2}$, and Thermal Expansion of $5 \times 10^{-6}{ }^{\circ} \mathrm{K}-1$.

Finite Element Method (FEM) or usually called Finite Element Analysis (FEA) is a numerical procedure that can be used to solve problems in the fields of engineering such as stress analysis on structures, personal frequencies and the shape mode, heat transfer, electromagnetic, and fluid flow. The element families most commonly used in a stress analysis (Figure 2). One of the major distinctions between different element families is the geometry type that each family assumes.
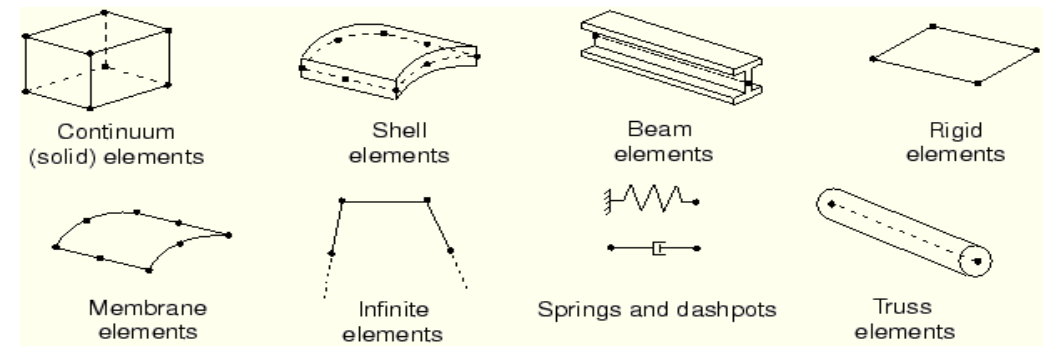

Figure 2. Commonly Used Element Families 
The element families that used in this final project is shell element. Shell elements are used to model structural elements where two dimensions are much larger than three dimensions, static analysis of panel elements and thin-walled spatial elements such as shells. The advantage of using shell elements is the result mainly of time savings due to reduced number of finite elements. To achieve the goal of this research, the author should fulfils the requirement of designing outer body of electric vehicle using CATIA software. This section covers several topics such as:

1. Establishing the Finite Element Tools

CATIA software is used to finish the final project. Tools could make the project become easier to design or simulate final project. The project using CATIA $5^{\text {th }}$ version for planning and designing processes of outer body of electric vehicle.

2. Establishing the Finite Element Von-Mises Stress

The value used to determine whether a material will produce or break is called Von Mises stress. The state of stress is described by the six Cauchy stresses $\left\{\sigma_{\mathrm{x}}, \sigma_{\mathrm{y}}, \sigma_{\mathrm{z}}, \tau_{\mathrm{xy}}, \tau_{\mathrm{xz}}, \tau_{\mathrm{yz}}\right\}$ which vary from point to point. The von Mises stress is a combination of these according to the following expression:

$$
\sigma_{V M}=\sqrt{\frac{1}{2}\left[\left(\sigma_{x}-\sigma_{y}\right)^{2}+\left(\sigma_{x}-\sigma_{z}\right)^{2}+\left(\sigma_{y}-\sigma_{z}\right)^{2}+6\left(\tau_{x y}^{2}+\tau_{x z}^{2}+\tau_{y z}^{2}\right)\right]}
$$

The equation above is used for 3-Dimensional element, it does not match with this final project which uses 2-Dimensional for the design. In the 2-Dimensional analysis has a slight difference where $\sigma 3=\tau \mathrm{xz}=\tau \mathrm{yz}=0$.

3. Stress-Strain Relationship

Here is the discusses material Stress-Strain relation for linear material. The stress is related to the strain by:

$$
\{\varepsilon\}=\left\{\varepsilon^{t h}\right\}+[\mathrm{D}]^{-1}\{\sigma\}
$$

Where, $\{\sigma\}$ is stress vector, [D] is elasticity or elastic stiffness matrix, $\left\{\varepsilon^{e l}\right\}=\{\varepsilon\}-\left\{\varepsilon^{t h}\right\}=$ elastic strain vector, $\{\varepsilon\}$ is total strain vector, and $\left\{\varepsilon^{t h}\right\}$ is thermal strain vector

The sign convention for direct stresses and strains is that tension is positive and compression is negative. For shears, positive is when the two applicable positive axes rotate toward each other.
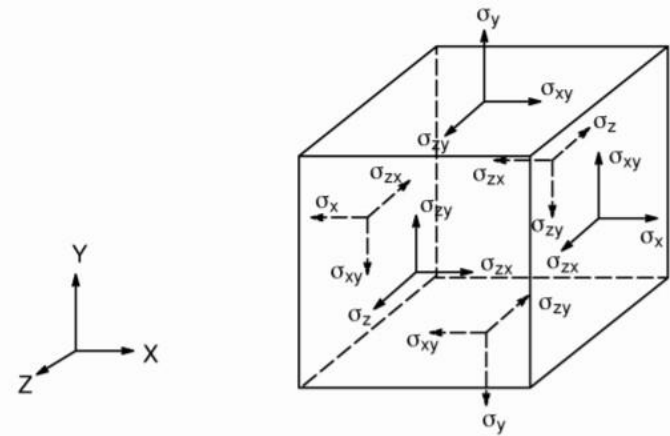

For the 3 Dimension case, the thermal strain vector is:

$$
\left\{\varepsilon^{t h}\right\}=\Delta T\left[\begin{array}{llllll}
\alpha_{\mathrm{x}} \mathrm{y} & \alpha_{\mathrm{z}} & 0 & 0 & 0 & 0
\end{array}\right]^{\mathrm{T}}
$$

Where, $\mathrm{E}$ is thermal coefficient of expansion in the $\mathrm{x}$ direction, $\Delta \mathrm{T}=\mathrm{T}-\mathrm{T}_{\mathrm{REF}} \mathrm{T}$ is current temperature at the point in question, $\mathrm{T}_{\mathrm{REF}}$ is reference (strain-free) temperature (input on $\mathrm{T}_{\mathrm{REF}}$ command).

The flexibility or compliance matrix, [D]-1, in "column normalized" format, is: 


$$
[\mathrm{D}]^{-1}=\left[\begin{array}{cccccc}
1 / \mathrm{E}_{\mathrm{x}} & -\mathrm{v}_{\mathrm{xy}} / \mathrm{E}_{\mathrm{y}} & -\mathrm{v}_{\mathrm{xz}} / \mathrm{E}_{\mathrm{z}} & 0 & 0 & 0 \\
-\mathrm{v}_{\mathrm{yx}} / \mathrm{E}_{\mathrm{x}} & 1 / \mathrm{E}_{\mathrm{y}} & -\mathrm{v}_{\mathrm{yz}} / \mathrm{E}_{\mathrm{z}} & 0 & 0 & 0 \\
-\mathrm{v}_{\mathrm{zx}} / \mathrm{E}_{\mathrm{x}} & -\mathrm{v}_{\mathrm{zy}} / \mathrm{E}_{\mathrm{y}} & 1 / \mathrm{E}_{\mathrm{z}} & 0 & 0 & 0 \\
0 & 0 & 0 & 1 / \mathrm{G}_{x y} & 0 & 0 \\
0 & 0 & 0 & 0 & 1 / \mathrm{G}_{y z} & 0 \\
0 & 0 & 0 & 0 & 0 & 1 / \mathrm{G}_{x z}
\end{array}\right]
$$

Where, $E_{\mathrm{x}}=$ Young's modulus in the $\mathrm{x}$ direction (input as EX on MP command)

$\mathrm{V}_{\mathrm{xy}}=$ minor Poisson's ratio (input as NUXY on MP command)

$\mathrm{G}_{\mathrm{xy}}=$ shear modulus in the $\mathrm{xy}$ plane (input as GXY on MP command)

\section{Load Calculation}

This method is based on a nonlinear optimization technique applied to an error function between the forces estimated by observers installed in the vehicle and those calculated by a theoretical tire/road interaction model. The friction coefficient is $\mu_{\mathrm{k}} 0.9$, [5] calculations can be planned with the following data:
a. Driver's mass
$: 70 \mathrm{~kg}$
b. Passenger's mass
: $70 \mathrm{~kg}$
c. Car's mass
: $450 \mathrm{~kg}$
Total
$: 590 \mathrm{~kg}$

So, for the vehicle force that happens is

$$
\begin{aligned}
\mathrm{N} & =\mathrm{m} \cdot \mathrm{g} \\
& =590 \cdot 9.81 \\
& =5787.9 \mathrm{~N} \\
\mathrm{~F} & =\mu \mathrm{k} \cdot \mathrm{N} \\
& =0.9 \cdot 5787.9 \\
& =5209.11 \mathrm{~N}
\end{aligned}
$$

It would be wise to calculate the wind force acting on the outer body of the electric vehicle. In this calculation has conditions when the electric vehicle runs with the maximum velocity and the winds toward to front face of the outer body (figure 3). The drag coefficient is $C_{D} 0.4$, here is the simple calculation of wind force:

Coefficient of drag $\left(C_{D}\right): 0.4$ [6]

$$
\begin{array}{ll}
\text { Velocity }(\mathrm{V}) & : 24 \mathrm{~km} / \mathrm{h}=6.67 \mathrm{~m} / \mathrm{s} \text { [7] } \\
\text { Density of air }\left(\rho_{\text {air }}\right) & : 1.18 \mathrm{~kg} / \mathrm{m}^{2}\left(25^{\circ} \mathrm{C}\right)[8]
\end{array}
$$

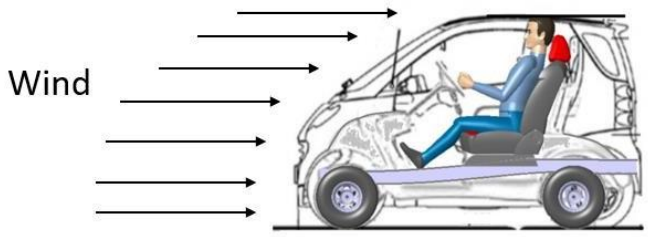

Figure 3. Winds Toward to Front Face of Outer Body 


$$
\begin{aligned}
\mathrm{A} & =\mathrm{b} \cdot \mathrm{h} \\
& =1260 \cdot 1625 \\
& =2047.5 \times 10^{3} \mathrm{~mm}^{2} \\
F_{D} & =\frac{1}{2} \rho v^{2} \mathrm{~A} C_{D} \\
& =\frac{1}{2} \cdot 1.18 \cdot 6.67^{2} \cdot 2.0475 \cdot 0.4 \\
& =21.49 \mathrm{~N}
\end{aligned}
$$

\begin{abstract}
Analysis
The outer body thickness comes in various thickness ranges such as 3 to $8 \mathrm{~mm}$. The tensile strength can be used to compare the maximum von mises stress, the thickness will be allowed if the maximum von mises stress is below the tensile strength value. Applying the force on the outer body obtained from the normal force multiplication by the coefficient of force. Collecting data is needed to complete the analysis, knowing the value of the force become the important thing. There are several data that are determined such as driver mass $(70 \mathrm{~kg})$, passenger mass $(70 \mathrm{~kg})$ and electric vehicle mass $(450 \mathrm{~kg}$ ), so the total load is $590 \mathrm{~kg}$. The outer body is not designed to hold electric vehicle from a crash, but it is designed to support the outer body of electric vehicle with the specific amount of force, by assuming someone pushing the electric vehicle with a stuck wheel condition. Stuck wheel condition makes the outer body will receive force much larger than the normal rotating wheel. The analyse at 3 point on the outer body, which is on the back-side, top- side and side body. Assuming force received by outer body from those point is the same force as the specified force in the previous sub-chapter. Since the design has very complicated shape, software is needed to analyse the design because it will be very difficult to calculate by manually.
\end{abstract}

\title{
Results and Discussions
}

The data collected in this final project are based on several information and also from the field to get dimensions by adjusting the size of the outer body. The writer collects all required data regarding the outer body analysis. The analysis is based on CATIA Generative Structure Analysis. In order to determine whether the design is really close to the intended design, it can apply an allowable load that is applied to the outer body.

- Electric Vehicle load : $\quad 450 \mathrm{~kg}$

- $\quad$ Electric Vehicle load + driver and passenger load $\quad$ : $590 \mathrm{~kg}$

Table 2. Electric Vehicle Body Dimension

\begin{tabular}{c|c|c|c|c}
\hline \multicolumn{3}{c|}{ Dimension } & Material \\
\hline Width & Length & Height & Mass & Fiberglass \\
\hline $1260 \mathrm{~mm}$ & $2350 \mathrm{~mm}$ & $1625 \mathrm{~mm}$ & $65.295 \mathrm{~kg}$ & \\
\hline
\end{tabular}

Mesh study is done by manual reduce mesh size. Reducing the size of elements in all modelling domains by manually and this method requires remeshing to get stable results. This method is chosen because it can analyse mesh with a surface-shaped designs, which use quadrangle method. In order to get more accurate results with a minimum error in calculations, element quadrangle is suitable to be applied to complex design structures.

The mesh study will be form 12 different samples of size, start from $20 \mathrm{~mm}$ to $8 \mathrm{~mm}$. This case is due to the complexity of the design so that the CATIA can only apply mesh as small as $8 \mathrm{~mm}$. 
Comparing the value of the Von-Mises stress is the way that able to determine the size of mesh. VonMises stress is obtained by taking three different nodes as in figure 4. To optimize the mesh study, the writer gives holes in the design to ensure that the nodes will remain the same in different mesh sizes. Von-Mises stress is obtained by applying the force to the top-side of the outer body.

The result show that the Von-Mises stress on node 1 and node 3 show instability, where the mesh size experiences an increase and also decrease. On the mesh size $12 \mathrm{~mm}$ to $11 \mathrm{~mm}$ shows constant Von-Mises stress. On the other hand, node 2 is quite stable increase on the mesh size $20 \mathrm{~mm}$ to 11 $\mathrm{mm}$ but there is a significant decrease afterwards. From that result, the writer is not able to determine the mesh size to be used so decided to do a re-analysis using a simpler design. On the second analysis is done using the same method as the first analysis. In a way reducing the size of elements by manually and also the same form, where is 12 different samples of size, start from 20 $\mathrm{mm}$ to $8 \mathrm{~mm}$. Von-Mises stress is obtained by taking three different nodes as in figure 6 . To optimize the mesh study, the writer gives holes in the design to ensure that the nodes will remain the same in different mesh sizes.

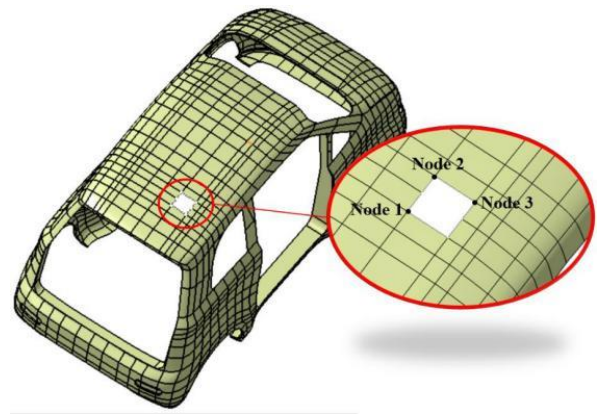

Figure 4. Nodes Placement

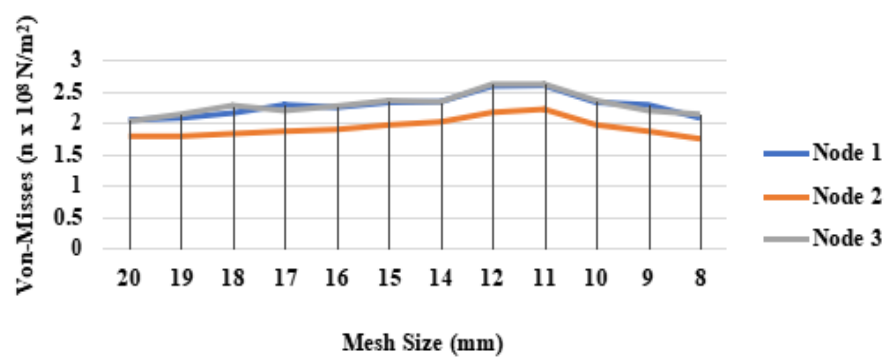

Figure 5. Meshing Study Result

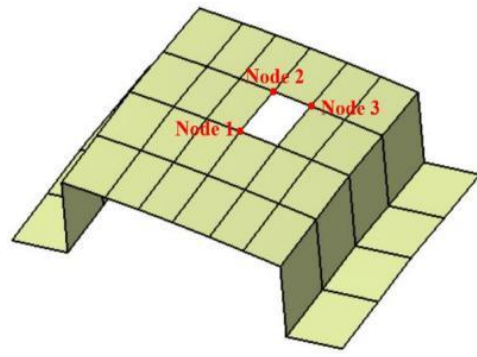

Figure 6. Nodes Placement on Simple Design

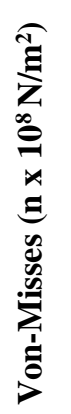

Figure 7. Meshing Study Result on Simple Design

From the second result, node 1, node 2 and node 3 show instability Von-mises stress on the mesh size $20 \mathrm{~mm}$ to $12 \mathrm{~mm}$. There are a constant Von-mises stress on the mesh size $12 \mathrm{~mm}$ to $11 \mathrm{~mm}$ and $10 \mathrm{~mm}$ to $8 \mathrm{~mm}$. The objective of mesh study is to find the stable value of Von-Mises stress. Based on the first result and the second result, the writer concludes that the suitable size of mesh for the outer body is $12 \mathrm{~mm}$ with global estimated error rate is $5.34 \%$ (see figure 8 ). This value is chosen after passing various considerations and also in some cases such as, a similarity between the first result and the second result where on the mesh size $12 \mathrm{~mm}$ to $11 \mathrm{~mm}$ show a constant Von-Mises stress. 


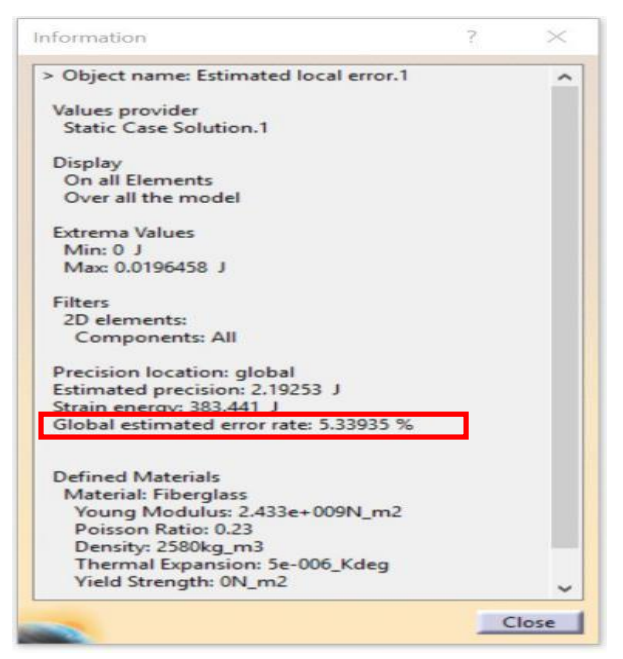

Figure 8. Global Estimated Error Rate

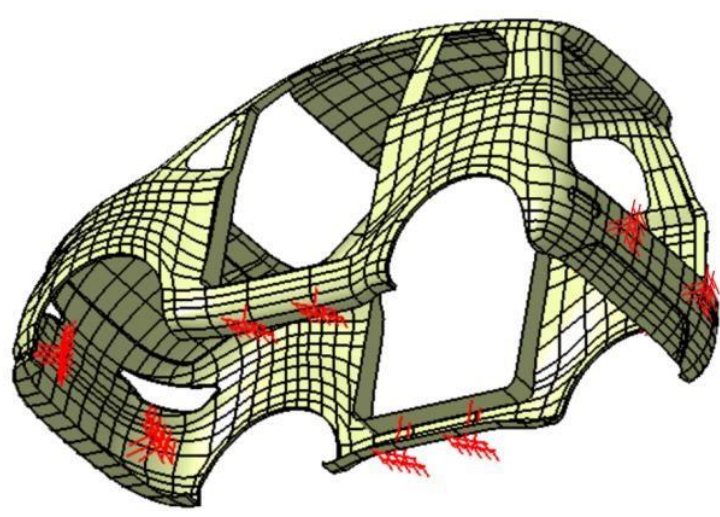

Figure 9. Design Clamping with 6 Fix Support

\section{Data Analysis}

The analysis is to find out the Von-Mises Stress that come up on the outer body of electric vehicle. This analysis was using CATIA 5th version, the loads are applied in order to find out the VonMises Stress. The loads are given into 3 locations separately (top-side, back-side and side body) with 6 fix support (two on the bottom, two on the front bumper and two on the rear bumper). These fix supports are based on the meeting point between the electric vehicle body and the bottom chassis (Fig. 9). The writer will find the thickness of the outer body which refers to tensile strength of the material. The analysis starts from a thickness of $3 \mathrm{~mm}$ then adds $1 \mathrm{~mm}$ thickness to get the Von-Mises stress results below the tensile strength.

(a)

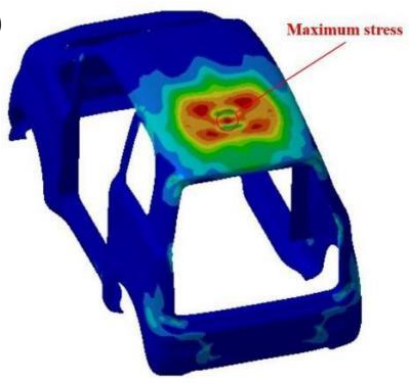

(b)

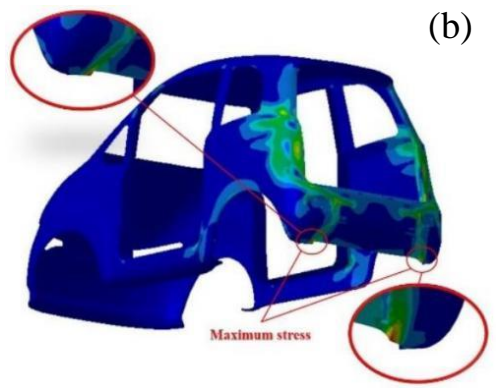

(c)

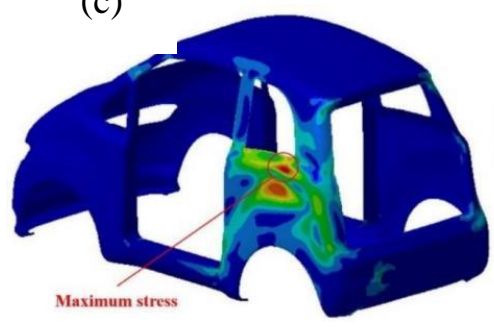

Figure 10. Simulation Model and Load Conditions of (a) Top-, (b) Back- and (c) Side Body

Table 3. Comparison Maximum Von-Mises stress

\begin{tabular}{c|c|c|c}
\hline \multirow{2}{*}{ Region } & \multirow{2}{*}{$\begin{array}{c}\text { Tensile Strength of } \\
\text { Fiberglass }\end{array}$} & \multicolumn{2}{|c}{ Maximum Von-Mises Stress } \\
\cline { 3 - 4 } & & $3 \mathrm{~mm}$ Thickness & $4 \mathrm{~mm}$ Thickness \\
\hline Top-Side Body & & $9.05 \times 10^{7} \mathrm{~N} / \mathrm{m}^{2}$ & $5.94 \times 10^{7} \mathrm{~N} / \mathrm{m}^{2}$ \\
Back-Side Body & $20.7 \times 10^{7} \mathrm{~N} / \mathrm{m}^{2}$ & $6.71 \times 10^{7} \mathrm{~N} / \mathrm{m}^{2}$ & $4.14 \times 10^{7} \mathrm{~N} / \mathrm{m}^{2}$ \\
Side Body & & $25.4 \times 10^{7} \mathrm{~N} / \mathrm{m}^{2}$ & $15.4 \times 10^{7} \mathrm{~N} / \mathrm{m}^{2}$ \\
\hline
\end{tabular}




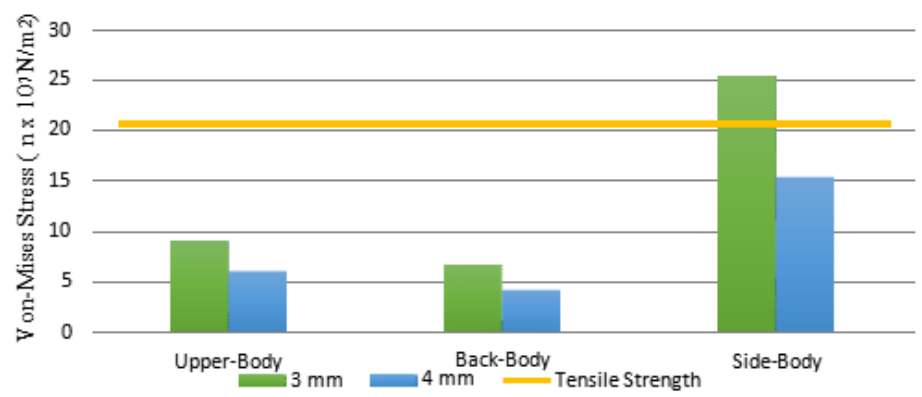

Figure 11. Equivalent of Maximum Von-Mises Stress

From the analysis, the maximum Von-Mises Stress on 3mm thickness that appears on the upper body and the back-body of electric vehicle is still within safe limits. On the side-body has higher maximum Von-Mises Stress than the value of Tensile Strength of fiberglass. It means the side body of electric vehicle is not safe, it will be fracture or crooked. Based on the result of Von-Mises stress with $4 \mathrm{~mm}$ thickness, the value of Maximum Von- Mises stress is below the tensile strength at all side of outer body. This analysis meets the criteria to be declared successful. The outer body with a thickness of $4 \mathrm{~mm}$ has been able to withstand a load of 5209.11 Newton. The writer determines that with a thickness of $4 \mathrm{~mm}$, the outer body will not fracture or crooked.

\section{Advanced Analysis}

The result from the previous analysis are quite satisfying, but have not met the requirements of the safety factor. In order to analyse the allowable stress which refers to the calculation of the safety factor. The $\mathrm{N}$ (safety factor) is taken from the general recommendation of safety factor (figure 12). Based on the table, the safety factor that is suitable for the project is $1.5-2$, which is the safety factor is for use with reliable materials where loading and environmental conditions are not severe. It can be seen the use of the outer body of an electric vehicle, where using materials that are reliable with loading and the environment conditions are not severe. For the outer body, this application is the most suitable than the others.

\begin{tabular}{|c|c|}
\hline Applications & $\begin{array}{c}\text { Factor of Safety } \\
\text { - FOS - }\end{array}$ \\
\hline $\begin{array}{c}\text { For use with highly reliable materials where loading and } \\
\text { environmental conditions are not severe and where weight } \\
\text { is an important consideration }\end{array}$ & $1.3-1.5$ \\
\hline $\begin{array}{c}\text { For use with reliable materials where loading and } \\
\text { environmental conditions are not severe }\end{array}$ & $1.5-2$ \\
\hline $\begin{array}{c}\text { For use with ordinary materials where loading and } \\
\text { environmental conditions are not severe }\end{array}$ & $2-2.5$ \\
\hline $\begin{array}{c}\text { For use with less tried and for brittle materials where } \\
\text { loading and environmental conditions are not severe }\end{array}$ & $2.5-3$ \\
\hline $\begin{array}{c}\text { For use with materials where properties are not reliable and } \\
\text { where loading and environmental conditions are not severe, } \\
\text { or where reliable materials are used under difficult and } \\
\text { environmental conditions }\end{array}$ & $3-4$ \\
\hline \begin{tabular}{c} 
end \\
\hline
\end{tabular} & \\
\hline
\end{tabular}

Figure 12. Determine the Factor of safety

The allowable stress can be expressed as follows:

$$
\begin{aligned}
\sigma_{a} & =\frac{\sigma_{u}}{N} \\
\sigma_{a} & =\frac{2.07 \times 10^{8} \mathrm{~N} / \mathrm{m}^{2}}{2} \\
\sigma_{a} & =1.035 \times 10^{8} \mathrm{~N} / \mathrm{m}^{2}
\end{aligned}
$$


The next step is to find the proper thickness of outer body based on the allowable stress. The thickness can be safe, if the value of Maximum Von-Mises stress is below the allowable stress. The method that will used for this analysis is the same as the method used in the previous analysis. The outer body applied load of 5209.11 Newton at 3 crucial points by alternately.

Table 4. Comparison Maximum Von-Mises Stress by Considering Safety Factor

\begin{tabular}{c|c|c|c|c}
\hline \multirow{2}{*}{ Region } & \multirow{3}{*}{$\begin{array}{c}\text { Allowable stress } \\
\text { Safety Factor is } 2)\end{array}$} & \multicolumn{3}{|c}{ Maximum Von-Mises Stress $\mathrm{n} \times 10^{7} \mathrm{~N} / \mathrm{m}^{2}$} \\
\cline { 3 - 5 } & & $4 \mathrm{~mm}$ & $5 \mathrm{~mm}$ & $6 \mathrm{~mm}$ \\
\cline { 3 - 5 } & & 5.94 & 4.23 & 3.16 \\
\hline Top-Side Body & & 4.14 & 2.80 & 2.02 \\
Back-Side Body & $10.35 \times 10^{7} \mathrm{~N} / \mathrm{m}^{2}$ & 15.4 & 10.8 & 8.74 \\
\hline
\end{tabular}

The result analysis of Von-Mises stress that appears on the top-side, back-side and side body is shown above. The allowable stress become parameters for this analysis, that determines the success or failure of a design. From the analysis, the upper body and the back-body on 5mm thickness has the maximum Von-Mises Stress still within safe limits. On the side-body has higher maximum Von-Mises Stress than the allowable stress, the side body of electric vehicle is not safe or design will be failure. Continued by the $6 \mathrm{~mm}$ analysis, it seems like the maximum Von-Mises Stress is not higher the allowable stress on all point region. The analysis is successful to get the proper thickness which is $6 \mathrm{~mm}$. In this case, the $6 \mathrm{~mm}$ thickness will not experience failure or fracture. In order to find the thickness of the outer body, the writer has finished the analysis start from $3 \mathrm{~mm}$ to $6 \mathrm{~mm}$ of the thickness. This is the data result that obtained from the analysis:

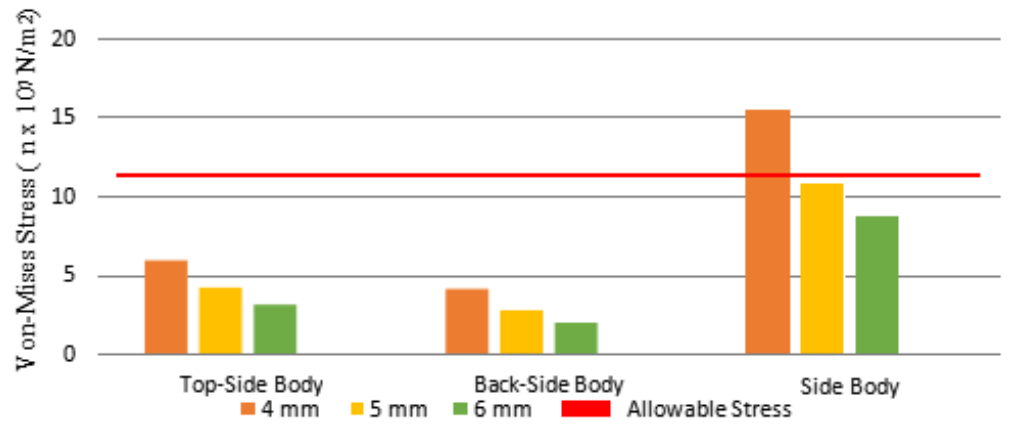

Figure 13. Equivalent of Maximum Von-Mises stress by considering safety factor

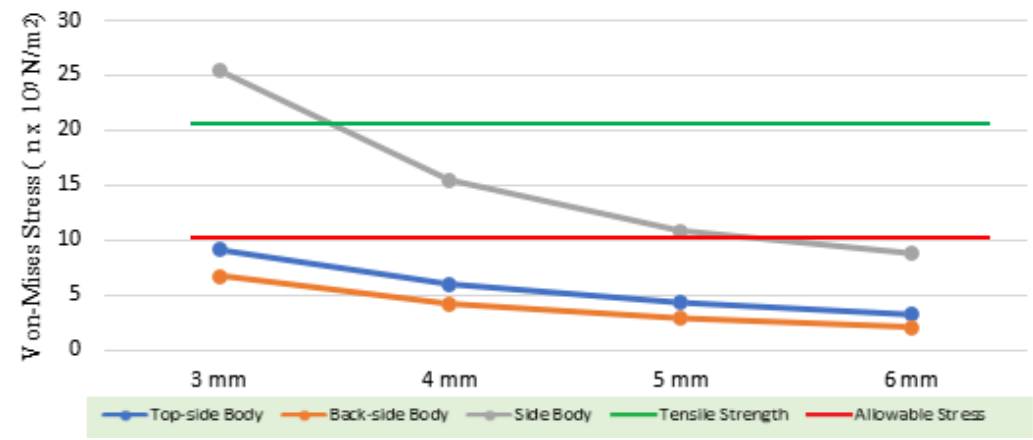

Figure 14. The Graph of Thickness Analysis 
Based on the graph above, top-side and back-side body are safe if based on both tensile strength and allowable stress. The main problem that occurs in this analysis is the side-body. On the $3 \mathrm{~mm}$ thickness, Maximum Von-Mises stress on the side-body exceeds the tensile strength value. The thickness is increased to $4 \mathrm{~mm}$. So, Maximum Von-Mises stress is an under tensile strength. In other words, the thickness of outer body is within the safe limit. When the thickness referring to the safety factor this thickness is not sufficient. Therefore, to prevent any failures happening on the design, allowances for the design must include the factor of safety. Meanwhile, allowable stress is obtained by referring to the safety factor. It same like the previous analysis, the problems only occur in the side-body of electric vehicle. The value of Maximum Von-Mises stress at $5 \mathrm{~mm}$ thickness is actually only slightly above the allowable stress. The writer decides to add a thickness of $1 \mathrm{~mm}$ to achieve maximum safety. In the analysis of $6 \mathrm{~mm}$ thickness, it shows Maximum Von-Mises stress is below the allowable stress. So that, the outer body of an electric vehicle with a thickness of $6 \mathrm{~mm}$ is within safe limits and not fractures.

\section{Conclusions}

Based on the result of this final project, there are several conclusions that could be presented to answer the objective of the research. There are some of the notable conclusions drawn were as follows:

1. Fiberglass (E-glass) was chosen as material to make the outer body because it turned out to be the most optimal choice among other alternative materials.

2. The outer body successful withstand the given load by the thickness of $4 \mathrm{~mm}$, where the Maximum Von-Mises stress is under the tensile strength $\left(20.7 \times 10^{7} \mathrm{~N} / \mathrm{m}^{2}\right)$. In other hand, the design is in the safe limit and will not failure. It would be wise if the design considers the factor of safety. So, the thickness that can withstand loads by considering the safety factor is $6 \mathrm{~mm}$.

3. In this project wind force is not analysed because the load given (21.49 Newton) to the external body is not very significant, which is only $0.41 \%$ from the analysis load (5209.11 Newton).

\section{References}

[1] Gelmanova, et al, 2018. "Electric cars. Advantage and Disadvantage". Kazakhstan: Karaganda State Industrian University.

[2] School of Electronic and Computer Science. "Pusat DIKLAT Mobil Nasional ESEMKA di Klaten”. Internet: http://eprints.ums.ac.id/21729/2/BAB_I.pdf [November 5, 2018].

[3] Otomotifo."7 Mobil Listrik Indonesia Terbaru 2019”. Internet: https://www.otomotifo.com/ mobil-listrik-indonesia-terbaru/ [November 5, 2018].

[4] Fiber-Tech, Inc. "Fiberglass Benefits, Why Choose Fiberglass over other materials". Internet: http://www.fiber-techinc.com/capabilities/extras/fiberglass-benefits/ [November 5, 2018].

[5] Kong, Xianguang; Qiu, Yuanying; Chang, Jiantao. 2012. "Research and Implementation of CATIA Tool Integration Technology Based on CAA". China: School of Mechano- electronic Engineering, Xidian University.

[6] Cengel, Yunus A; Cimbala, John M. 2010. "Fluid Mechanics Fundamentals and Applications". Boston: McGraw-Hill Higher Education.

[7] Club car. 2004. "Precedent and Precedent Villager 4 Gasoline and Electric Vehicles". Augusta, Georgia 30917-4658 USA.

[8] Hibberler, R. C. 2011. "Mechanics of Materials". Pearson Prentice Hall. 